\title{
UPPER JURASSIC - LOWER CRETACEOUS DEPOSITS IN THE SOUTH-WESTERN PART OF PĂDUREA CRAIULUI. FORMAL LITHOSTRATIGRAPHIC UNITS
}

\begin{abstract}
IOAN COCIUBA ${ }^{1}$
ABSTRACT. The paper describes the Upper Jurassic - Lower Cretaceous deposits of the Bihor Unit from Pădurea Craiului Mountains, according to the International Stratigraphic Guide. All the previously described formations are included; besides, new formations are defined in case of deposits which were not previously described in agreement with this code. The Upper Jurassic units here described are Vad, Cornet, Aştileu, and Albioara Formations (the last one divided into Secătura and Valea Cuților Members). The corresponding Lower Cretaceous units are: Blid Formation (divided into Dobreşti and Coposeni Members), Ecleja Formation (partly divided into Gugu and Valea Bobdei Members), Valea Măgurii, and Vârciorog Formations. The age of each formation is documented on the content of foraminifers and algae or on the ammonite species where appropriate.
\end{abstract}

KEYWORDS: Pădurea Craiului, Upper Jurassic, Lower Cretaceous, lithostratigraphic units, benthic foraminifera, calcareous algae.

\section{INTRODUCTION}

Pădurea Craiului Massif is located in the northwestern part of the Apuseni Mountains. It is separated from the central body of the Apuseni Mts. by the southeastern line of Remeți Graben and it extends towards northwest between Vad-Borod Depression (to the north) and Beiuş Depression (to the south).

The present day outlook of the Pădurea Craiului Massif is the result of a long lasting evolution that started before the Hercinic cycle but which was mainly connected with the sedimentary processes and the tectonic stages of the alpine orogenesis.

As far as the facies, succession of deposits, as well as the present day structure is concerned, most of the surface of Pădurea Craiului Massif can be included into the Bihor Unit of the Northern Apuseni Mts. On small areas, in the southwestern part, deposits attributed to the Codru Nappe System outcrop.

Our study was focused mainly on the lithological, biostratigraphical and structural investigation of the Upper Jurassic and Lower Cretaceous deposits from Bihor Unit in Pădurea Craiului Massif. The results of this investigation are briefly presented in the paper (which is, in fact, an abstract version of the PhD thesis, Cociuba, 1999) and they represent some answers to questions arised during fieldwork; many other questions are still opened.

\footnotetext{
1 "Geological Institute of Romania", Cluj-Napoca Branch, Horea street, 78, 3400 Cluj-Napoca, Romania
} 


\section{IOAN COCIUBA}

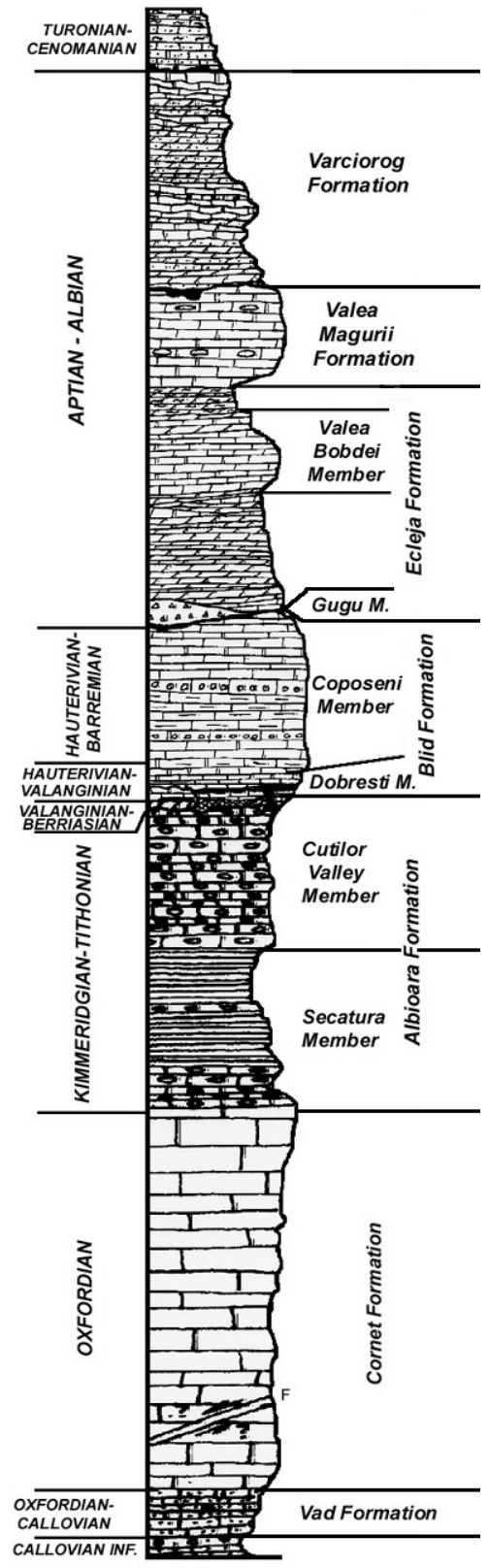

Fig.1. The synthetic lihtological column of the Upper Jurassic - Lower Cretaceous formations from the south-western Pădurea Craiului.
The Mesozoic formations in Pădurea Craiului Massif were partly described as formal units which only partly correspond to the International Stratigraphical Guide (Hedberg Code) (Salvador, 1994). The Upper Jurassic - Lower Cretaceous deposits in Pădurea Craiului Massif are presented bellow, in agreement with the standard practice. The previously separated formations (by authors mentioned in the text) are revised and new units are proposed in the case of formations that were not correctly described (Fig. 1).

\section{BRIEF HISTORICAL APPROACH}

Starting with 1850 and until the 70's several authors published significant references concerning Pădurea Craiului Massif: Szontagh (1904), Fisch(1924), Kräutner (1941), Preda(1963), Istocescu (1969), Patrulius (1956, 1971), Patrulius et al. (1968), Bordea \& Istocescu (1970), Popa (1981) etc.

The synthesis on the geology of Apuseni Mts. coordinated by lanovici (1976) contains a part on the geology of Pădurea Craiului Massif written by Patrulius. This work established valid formal divisions of lithostratigraphical units within Triassic and Upper Jurassic, but not for the Lower Cretaceous, with one exception (Ecleja Formation). Following this paper, other detailed works approached certain areas or stratigraphic stages and brought significant changes in the knowledge on the stratigraphy and tectonics of Pădurea Craiului. The papers of Jurcsák \& Popa (1978) about rests of dinosaurs within a boehmite bauxite lens at Cornet and that of Patrulius et al. (1982) on the genesis, stratigraphy and tectonic significance of an extended breccia horizon in the central part of Pădurea Craiului Mts. (defined by the authors as "Gugu Breccia", of Bedoulian age) are worth to be mentioned. Dragastan et al. (1982) investigated the Triassic biostratigraphy and, based on an algal association, proved that the top of Weterstein-type limestone includes also the basal Upper Triassic (Carnian deposits). Săndulescu (1984) includes the Northern Apuseni Mts., as well as several (Bakony, Mecsek, Villàny, and Bukk), and from 
the Western Carpathians in Slovakia within the "Internal Dacides". The author considers that the Bihor Unit is, in its turn, overlaying the Pienides and/or Transylvanides, thus he changes the name of "Bihor Autochthonous", as considered by lanovici et al. (1976), into "Bihor Unit".

\section{UPPER JURASSIC DEPOSITS}

1. Vad Formation. (Patrulius et al., 1974, rap., Patrulius, in lanovici et al., $1976=$ Vad Limestone)

Definition: dark grey stratified limestone, frequently showing blackish siliceous decimetric nodules (in the lower part). They are characterized by homogeneous pelmicrosparitic or pelsparitic microfacies and generally by scarce macrofauna.

Lower boundary: below the first limestone bank which cover the marls and sandstones with Callovian ammonites (lithological boundary).

Upper boundary: gradual passage to massive, light colored limestone. The boundary can be arbitrary drawn on the top of the last beds of stratified grey limestone.

Type-locality: the limestone quarry from Vadul Crişului, on the left side of Crişul Repede River, at the exit from the gorge sector.

Age: Late Callovian-Oxfordian-Kimmeridgian-? Early Tithonian (cf. Patrulius, in lanovici et al., 1976).

Remrks: According to Patrulius (in lanovici et al., 1976), Vad Limestone does not include the thin (sometimes submetric) carbonate formations represented by slightly nodular marly limestone, or the grey-yellowish pelitic limestone with scarce belemnites and ammonites corresponding to Anceps zone (Middle and Upper Callovian). Taking into account their lithology (dominated by limestone) and their reduced thickness which does not allow a cartographic separation, as well as the fact that Vad Formation represents the begining of a different sedimentary cycle (of a carbonate platform) as compared to the previous one, we considered as necessary to include these interlayers into the basal part of the Vad Formation.

In the southwestern part of Pădurea Craiului the age of this formation is considered to be not older than the basal Oxfordian (Fig. 1). The proof is the fact that the upper boundary of the overlaying Cornet Formation was located at the Oxfordian-Kimmeridgian boundary (based on Alveosepta jaccardi). Though, the specific situation in Cuților Valley cannot be extrapolated in the central and northeastern part of Pădurea Craiului, where the formation is considerably thicker and thus the time of deposition can be significantly different.

2. Cornet Formation (Patrulius et al., 1974, rap., Patrulius, in lanovici et al., $1976=$ Cornet Limestone, p.164, + Farcu Limestone, p. 165)

Definition: massive light grey, sometimes slightly brownish limestone (50$80 \mathrm{~m}$ thick), characterized by sparitic microfacies with intraclasts, bioclasts, oncoliths, and reefal constructions in growth positions. In the basal part, encrinitic calcarenites were often noticed. 
Lower boundary: on the top of the last beds of dark grey limestone of Vad Formation (when it is present, a gradual transition is characteristic) or below the first beds of light grey limestone overlaying the carbonate cemented sandstones with ferriferous ooids, or the limestone with brown nodules of the Lower Callovian formations (lithological boundary, when a red color sometimes characterizes the basal levels)

Upper boundary: below the first beds of dark grey stratified limestone of the Albioara Formation (gradual transition) or below the first beds of fine, micritic Lower Cretaceous limestone with characeeans and ostracods, or eventually below the bauxite lenses, when they are present (erosional boundary).

Type-locality: the central part of Pădurea Craiului, probably in the neighborhood of the headquarters of the Mining Enterprise from Cornet, in the right (eastern) slope of Mnerăie Valley.

Complementary section: the slope of Farcu Hill towards Şteazelor Valley.

Age: Oxfordian-Kimmeridgian-Middle Tithoninan (Patrulius, in lanovici et al., 1976; this paper, based on foraminifer assemblage).

Remarks: The above description covers the formerly described "Cornet Limestone" and "Farcu Limestone"; the original description of the two units is practically identical, the only difference being the fact that the Farcu Limestone shows "a generally finer and less homogenous microfacies" than the Cornet Limestone. The original description clearly mentions that these two formations can be hardly differentiated while in the field their separation as distinctive cartographic units "is practically impossible". Our suggestion, according to the page priority, refers to the usage of the formal unit Cornet Formation without including the oolitic limestone of Aştileu Formation, which can be easily separated and are well defined by their characteristic lithology.

At the upper part of this formation, in the profile in Cuților Valley we identified a foraminiferal assemblage with Alveosepta jaccardi (PI. 1, fig. 1). The association is characteristic for Upper Oxfordian-Lower Kimmeridgian and, it is largely spread within the wholeTethys. The age of the foraminiferal assemblage is confirmed by ammonites association, thus several authors separated the Alveosepta jaccardi biozone (Azema et al., 1977, Pélissié et al., 1984, Tasli, 1993).

This association is not restricted to the upper boundary of the massive limestone of Cornet Formation; it continues for about $4 \mathrm{~m}$ within the stratified, oncolithic limestone of Albioara Formation.

Under these circumstances we consider that the Oxfordian - Kimmeridgian boundary coincides with the upper boundary of Cornet Formation, at least in the section from Cuților Valley. In other areas, such as the central-northern one, the age of the formation extends up to the Middle Tithonian.

3. Aştileu Formation (Patrulius et al., 1974, rap., Patrulius, in lanovici et al., 1976 = Aştileu Limestone)

Definition: massive, light grey limestone dominated by oosparitic microfacies (oosparites, oopelsparites and biopelsparites)

Lower boundary: below the first beds of light grey oolitic limestone.

Upper boundary: below the bauxite lens or below the first beds of dark grey stratified limestone, with characeeans and ostracods. Erosional boundary. 
Type-locality: western flank of Butan anticline, on the western slope of Şerbota Hill, right southwards from Aştileu village (the refractory bricks plant).

Age: Kimmeridgian-Tithonian (?Lower) (Patrulius, in lanovici et al., 1976).

4. Albioara Formation. (Patrulius et al., 1974, rap., Patrulius, in lanovici et al., 1976 = Albioara Limestone) .

Definition: dark grey limestone (rarely with light colored interbeddings), with decimetric stratification (rarely showing metric beds), generally microsparitic but also micritic towards the base, with large, centimetric oncolithic structure which are lighter in color.

Lower boundary: below the first beds of dark grey stratified limestone which outcrop on the top of the previous formation, consisting of grey massive limestone. Gradual transition with continuity of sedimentation.

Upper boundary: below the first beds of fine light grey limestone with characeeans and ostracods or below the bauxite lens (erosional boundary).

Type-locality: left slope of Albioara Valley, at the northern extremity of the gorge sector. Cociuba, 1999)

Age: Kimmeridgian-Middle Tithonian (Patrulius, in lanovici et al., 1976;

Remarks. In Albioara gorge, where the stratotype of this formation was defined, the outcrop is very well opened but in the northern end, the lower part of this formation is missing due to a major fault which hides its contact with the underlying unit (Cornet Formation). Even if in this area the first beds of limestone are finer, micritic, with centimetric stratification, they were not studied in details before, being sometimes attributed to Lower Cretaceous which is located in the neighborhood, in a tectonic position. Due to this reason, all the previous authors insisted on the oncolithic and microsparitic character of this limestone.

In the areas where fine micritic limestone (even showing a fenestral lamination) having a similar fauna with that described from Albioara Formation were identified, a new lithostratigraphic unit was separated: Secătura Limestone (Bordea \& Bordea, 1987). In the section from Pleş-Cuților Valley where the whole Upper Jurassic succession is very well exposed, both the lower and the upper boundaries of the formations are visible. The lower part of the formation is mainly micritic, sometimes with fenestral lamination, with subdecimetric bedding and shows rare oncolithic interbeds. It can be relatively easily separated from the upper part, where more or less oncolithic microsparitic limestone dominates.

Taking into account all these features, we consider that the original definition of the formation should be kept, in agreement with the type-section where the micritic limestone is also present in the basal part. We support the idea of deboundarying two terms having a member rank due to the relative high thickness of the formation and to the practical criteria of separation in the field. For the lower subunit we suggest "Secătura Member" (= Secătura Limestone, cf. Bordea \& Bordea, 1987), while for the upper subunit we introduce "Valea Cuților Member".

4. 1. Secătura Member. (Bordea \& Bordea, 1987 = Secătura Limestone) Definition: dark grey micritic fenestral (sometimes with fenestral lamination) limestone with centimetric to decimetric bedding, rarely microsparitic limestone with oncoliths. 
Lower boundary: below the first beds of dark grey, stratified limestone outcropping on the top of the previous formation, consisting of grey massive limestone. Gradual transition with continuity of sedimentation.

Upper boundary: arbitrary boundary, on the top of the last beds of fine, micritic, and dark grey limestone. Gradual transition.

Type-locality: Secătura Hill (in the eastern part of the hill), northeast from Şteazelor Valley.

Age: Kimmeridgian (Bordea \& Bordea, 1987; Cociuba, 1999 based on foraminiferal assemblage).

Remarks: In the section from Pleş Hill-Cuților Valley Fig.2, 3), where it outcrops along the whole thickness, Secătura Member sums up about $28 \mathrm{~m}$ and it is fine (micritic or microsparitic), dark grey with decimetic beds, with fenestrate structures, sometimes laminitic and rare biopelsparite interlayers. It presents some oncolithic levels with metric thickness; the basal one is the thickest $(4 \mathrm{~m})$ and contains an assemblage with Alveosepta jaccardi (SCHRODT) (PI. I, fig. 1), A. powersi (REDMOND), Streptocyclammina mulucensis HOTTINGER, Redmondoides lugeoni (SEPTFONTAINE), Parurgonina caelinensis CUVILLIER et al. (PI. 1, fig. 3) and Neokilianina rahonensis (FOURY \& VINCENT).

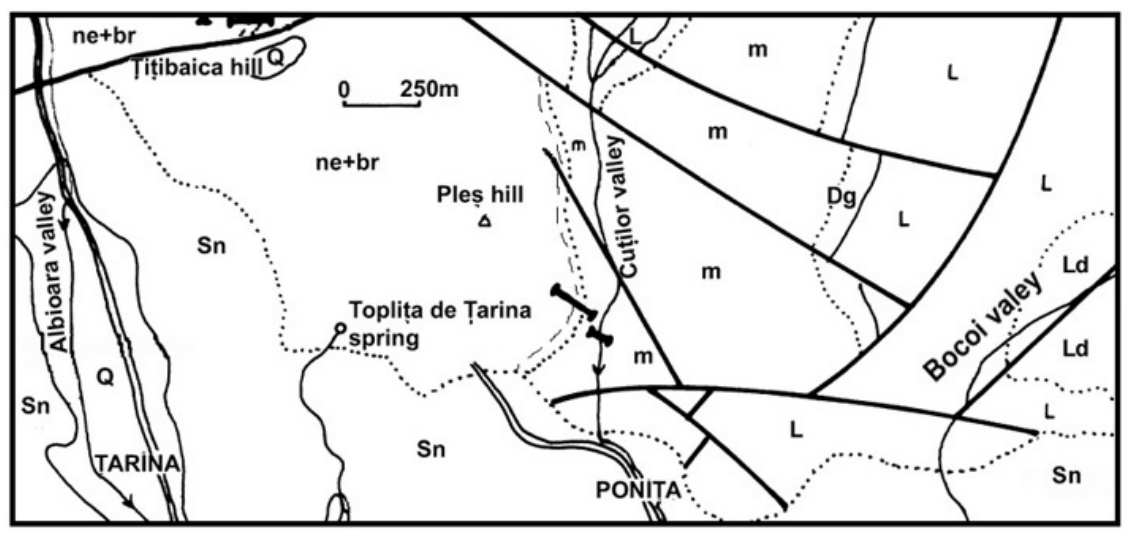

\section{LEGEND to Fig.2,4 and 6}

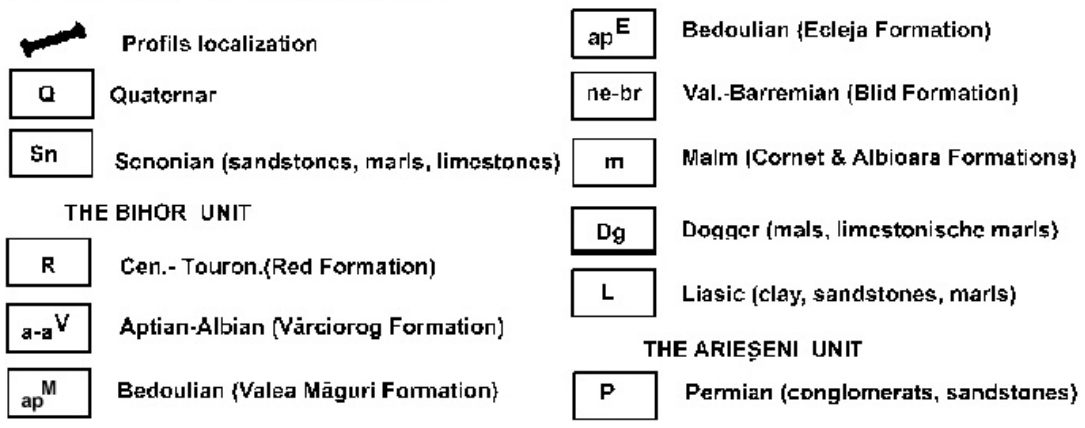

Fig. 2 - Location of the section in Cuților Valley - Pleş Hill, including the type section of Valea Cuților Member. 


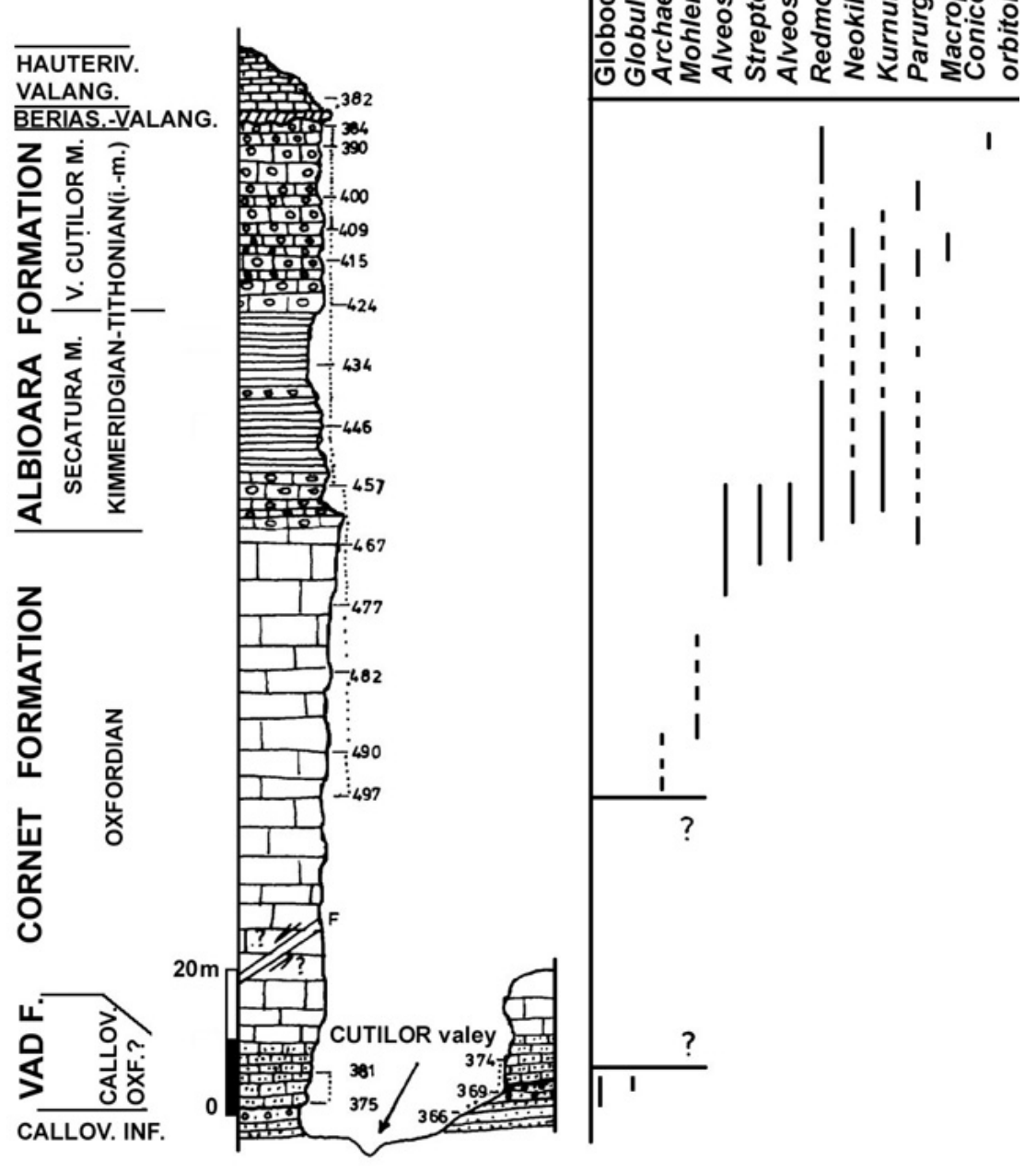

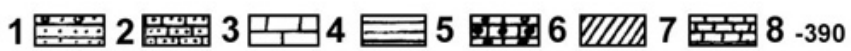

Fig. 3 - Cuților Valley - Pleş Hill section. 1. Calcareous sandstones; 2. Dark-gray pelsparitic limestones; 3. Light-gray limestones; 4. Dark-gray micritic limestones; 5. Microspariticoncoidic limestones; 6 . Bauxites; 7. Characean-bearing limestones; 8. Samples. 
Beside this association which characterizes the first meters and which represents a continuation from the previous formation, the micropaleontological content of these limestone is poor. We could identify Kurnubia palastiniensis HENSON, Alveosepta sp., Streptocyclamina sp. Thaumatoporella parvovesiculifera (RAINERI) and rare glomospires, valvulinides, miliolids and ostracods. Recently we identified the species Salpingoporella grudii (RADOIČIĆ), mentioned also by Dragastan et al., 1988, associated with Alveosepa jaccardi in a sample from borehole no. 8 Parina, meter 310 . This species confirms again the Kimmeridgian age of the formation.

Mention should be made that the name Secătura (as Secătura sandstone) appears on the geological map 1:50 000, Poiana Botizei Sheet (Săndulescu et al., 1981), but it is no formal description of this lithostratigraphic unit.

\section{2. Valea Cuților Member nomen novum}

Definition: dark grey limestone (rarely with light colored interbedding), with decimetric (rarely metric) layers, generally microsparitic with large centimetric oncoids showing lighter colors.

Lower boundary: arbitrary boundary on the top of the last beds of fine micritic, dark grey limestone (gradual transition).

Upper boundary: below the first beds of fine, dark grey limestone with characeeans and ostracods, or below the bauxite lens (erosional boundary).

Type-section: the right slope of Cuților Valley, below Pleş Peak and below the outcrop of bauxite lens no. 79/50 (mining sector Roşia-Albioara) (Fig. 2, 3).

Age: Kimmeridgian-Middle Tithonian, based on the foraminiferal assemblage.

Remarks: Bordea \& Bordea (1987) mentioned the presence of some "primitive orbitolinids" within Albioara Limestone, which were not identified as distinctive species (the authors mentioned some similarities with Parurgonina caelinensis). Bordea \& Bordea (1987) assume at least an Early Berriasian age for the upper boundary, while for the bauxite on its top the authors assume a Valanginian, Hauterivian or even Early Barremian age.

In the section in Pleş Hill - Cuților Valley, on the top of the limestone of Secătura Member, grey and dark grey, decimetric to metric stratified, microsparitic limestone follows, with large centimetric oncoids (Fig. 1), of a total thickness of 25 meters.

The microfacies of this limestone is dominated by more or less oncolithic microsparites, but pelmicrosparites are frequent and rare biopelmicrosparites were also noticed. The micropaleontological content is very scarce, especially right on the top of the bauxite. Almost all the forms we identified are largely distributed in the Upper Jurassic of the Tethys area. Still, some of the forms do not surpass the Tithonian (Kurnubia, Parurgonina), while Neokilianina rahonensis (which is sometimes present even at levels below the bauxite lens) does not surpass Kimmeridgian, exceptionally the Lower Tithonian (Septfontaine, 1988). Conicokurnubia aff. orbitolinideformis SEPTFONTAINE, 1988, species which we have recently identified in a sample collected just below the bauxite level, was described and identified only from Kimmeridgian formations. Taking into account that no Upper Tithonian species sensu strictu were identified, we consider that Upper Tithonian deposits are absent within the studied section. 


\section{LOWER CRETACEOUS DEPOSITS}

1. Blid Formation (Dragastan et al., 1986-in Bihor Mountains, Dragastan et al., 1988-in Pădurea Craiului)

Definition: transgressive succession of grey, stratified, micritic sometimes fenestral and bioclastic limestone with ostracods, miliolids, dasyclads, orbitolinids and rudists. We also include in this formation the discontinuous accumulations of bauxite in the basal part.

Lower boundary: on the top of the last beds of limestone of the Upper Jurassic formations (transgressive and erosional boundary).

Upper boundary: below the first beds of Ecleja Formation. (lithological and erosional boundary).

Type-locality: Blid Hill, the slope towards Crişanului Valley, Bihor Mountains (Dragastan et al., 1986; 1988).

Age: Barremian-Early Aptian (in Bihor Mts. and Pădurea Craiului, after Dragastan et al., 1988); Berriasian?-Valanginian-Hauterivian-Barremian (in Pădurea Craiului, Bucur \& Cociuba, 1996, 1998; this paper).

Remarks. The above mentioned data are taken from Dragastan et al., 1986, and refer to the succession in the type-section from Bihor Mts. This lithostratigraphical unit (defined without including the bauxite) was extended (Dragastan et al., 1988) to Pădurea Craiului area, but in our opinion the age boundaries are slightly different.

We consider that the discontinuous bauxite accumulations from its basal part should be included in the description of the formation.

Taking into account the data collected during the bauxite exploration by boreholes and the practical importance of a detailed study of these deposits in Pădurea Craiului, we suggest the separation of two distinctive members, easly also to be observed in the field: Dobreşti and Coposeni Members respectively, which are described below.

1.1. Dobreşti Member nomen novum (Patrulius, in lanovici et al., $1976=$ limestone with characeeans)

Definition: stratified, dark grey limestone with rare light colored interbeds, with characeeans, ostracods and microgasteropods. In the basal part it has discontinuous accumulation of diasporic bauxites, while between the (submetric, in general) limestone beds or in the paleorelief structures sometimes breccia with red clay matrix, polychrome clays, marly clays or boehmitic bauxites can be identified. boundary).

Lower boundary: on the top of the Upper Jurassic formations (erosional

Upper boundary: arbitrary boundary on the top of the last bank of dark grey limestone with characeeans, ostracods and small gastropods (gradual transition).

Type-section: the right slope of Vida Valley on the top of the outcrop of bauxite lens no. $162 \mathrm{~B}$, mining perimeter Luncasprie, Vida sector Fig. 4, 5).

Age: Berriasian?-Valanginian-Hauterivian, based on calcareous algae and foraminiferal assemblages (Bucur \& Cociuba, 1996; 1998; Cociuba, 1999). 
Remarks. The succession of Dobreşti Member agrees with the definition of a "Bauxite formation", sensu Bardossy (1977): "a stratigraphic succession which includes one or more bauxite complexes".

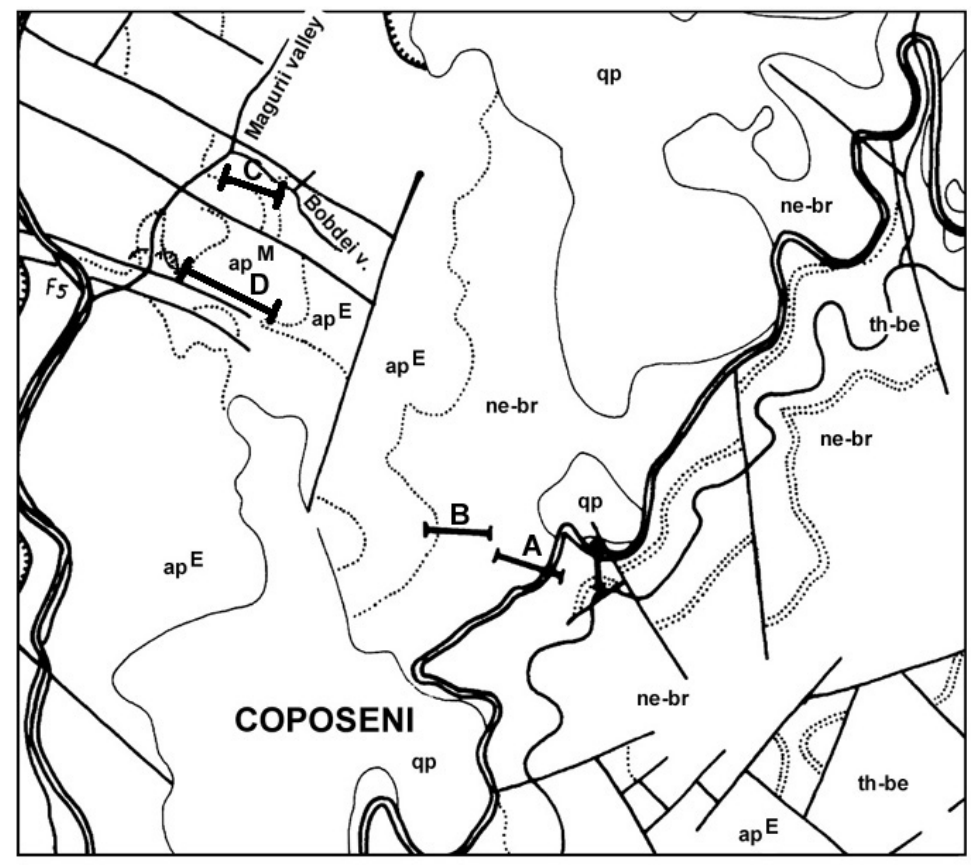

Fig. 4 - Location of the type sections of the Dobreşti Member (A), the Coposeni Member (B), the Valea Bobdei Member (C) and the Valea Măgurii Formation (D).

The first term of Dobreşti Member, which was discontinuously accumulated within the paleocarst of the malmian limestone consists of a diaspore bauxite. Together with the bauxitic clays that can be sometimes noticed at the top of the bauxite lens, they form a "bauxitic complex", sensu Bardossy (1977): "rocks with a homogeneous genesis, including bauxite." The clays or detrital material that reached the bauxite lens as a result of recent karst movements are not considered here.

On the top of diaspore bauxite or directly over the Jurassic limestones, the Dobreşti Member is overlaid by dark grey or even black limestone, submetric layered, with thickness between 0.5 to $3-4 \mathrm{~m}$, up to over $15 \mathrm{~m}$, on the top of the large bauxite lenses.

In the succession of dark grey limestones with characeeans, in the southwestern part at 4 to $5 \mathrm{~m}$ on the top of bauxites, local interlayers of red clays with ferriferous ooids and yellowish marly clays with centimetric rounded fragments of Jurassic limestones can be noticed. In the pițibaica Hill and in the left slope of the Albioara Valley the whole succession is not more than $0.5-0.7 \mathrm{~m}$ thick. In other areas a slightly pronounced paleorelief filled in the deeper parts with white kaolinitic clay with hardly noticeable disseminated white ooids was identified (lens 130 in the left slope of the Vida Valley). On the top of lens $119 / 115$, in the same left slope of Vida Valley, even ooidic bauxite is present. 


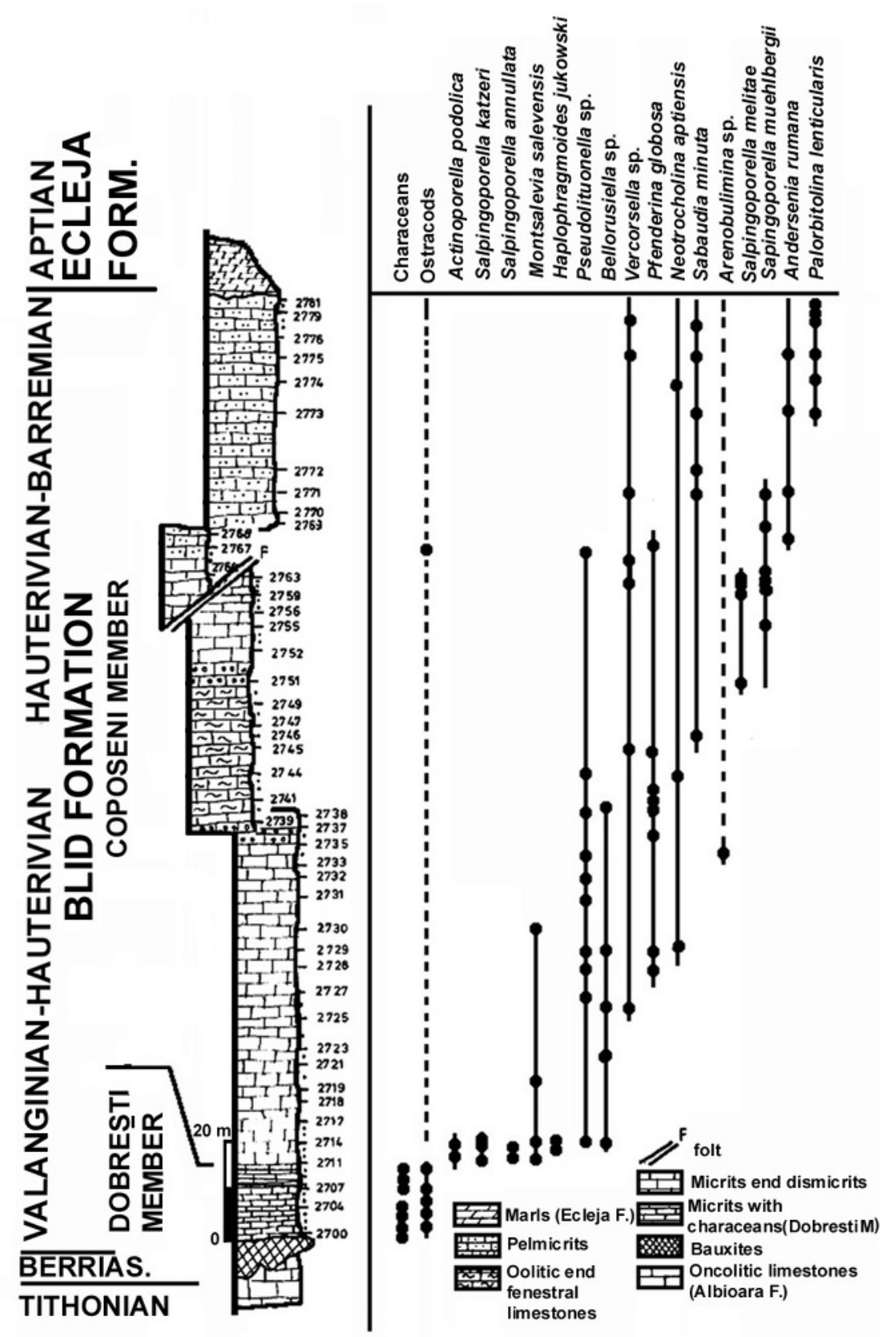

Fig. 5 - Section through Blid Formation at the type locality of the Dobreşti and Coposeni members. 
These deposits reflect the oscillating character of the first stages of the transgression represented by short regressive stages, which did not generate deep paleorelief surfaces reaching the Jurassic limestones in the south-western part of Pădurea Craiului. In the central-northern part of Pădurea Craiului, these oscillating movements seem to have had a wider amplitude so that the short uplift stages caused breccification of the beds of limestone with characeeans; sometimes the karstification of the deeper areas took place, even at lower levels than those reached by the lens of the first karstification process. Based on similar deposits found near lens of diasporic bauxite in this region several stages in paleocarst evolution were separated, each of them with a specific filling. The industrially extracted bauxite (containing diaspore) represent the filling of the first stage. The other two stages (with a reduced amplitude of the karstification processes) are characterized by fillings with crystallized calcite, by stratified boehmitic kaolinitic bauxite, marls with ostracods, whitish-pink kaolinitic masses. All these deposits contain fragments of Jurassic limestone or of dark grey limestone with characeeans and sometimes skeletal fragments of vertebrates. These karst voids cross the diaspore bauxite of the first stage (fragments of this bauxite being reworked in the deposits they fill-in) and they usually show locations lower than the bauxite of the first stage (Patrulius et al., 1982, rap.).

In our opinion, the karst voids formed during the last two stages are in connection with the two hardgrounds which were noticed in the sequence of Dobreşti Member, and they represent underground deposits formed in the contemporary karst of these surfaces (as a proof are the fragments of limestone with characeeans which were noticed by Patrulius et al., 1982, rap.).

In the type-section from Vida Valley-Coposeni, which contains the bauxite lens $162 \mathrm{~B}$ in the basal part, no interbed or hardground surface are to be seen; thus, we defined several complementary sections: Şerbota, Cornet and Pițibaica profiles.

1. 2. Coposeni Member nomen novum (Patrulius, in lanovici et al., $1976=$ Lower pachyodont limestone).

Definition: thick succession (sometimes more than $300 \mathrm{~m}$ ) of grey limestones, with metrical beds, dominated by fine micritic facies, more or less fenestrated (sometimes with fenestral laminations); also bioclastic-sparitic or ooidal facies are present, in which macrofauna is mainly represented by rudists.

Lower boundary: arbitrary boundary on the top of the last beds of dark grey stratified limestone with characeeans, ostracods and small gastropods belonging to Dobreşti Member (gradual transition).

Upper boundary: on the top of the last bed of limestone laying below the marls or marly sandstones of the Ecleja Formation (lithologic and erosional boundary), or below the massive breccia of Gugu Member within the same formation (erosional boundary).

Type-section: Vida Valley - Coposeni, between the limestone of the Dobreşti Member in the lower part and the marls of the Ecleja Formation (in Osoiului Hill), in the upper part (Fig. 4, 5).

Age: (?Late) Hauterivian -Late Barremian (based on calcareous algae and foraminiferal assemblages: Bucur et al., 1993; Bucur \& Cociuba, 1996; Cociuba, 1995, 1999). 
Remarks. The separation of Coposeni Member from other carbonate levels developed in an urgonian facies within Ecleja Formation or on its top was not clearly solved until now, as can be noticed on the previous geological maps of the region. The section in Vida Valley - Coposeni can be considered as a benchmark in defining the lithology and the micropaleontological assemblage of "the lower pachyodont limestone".

The age of this succession, on its first $50-60 \mathrm{~m}$, is Valanginian-Hauterivian (Late Hauterivian?) based on the following species: Salpingoporella katzeri CONRAD \& RADOIČIĆ (PI. 1, fig. 4), Salpingoporella annulata CAROZZI, Clypeina parasolkani FARINACCI \& RADOIČIĆ, Haplophragmoides joukovskyi CHAROLLAIS et al. (PI. 1 fig. 2), Montsalevia salevensis CHAROLLAIS et al. (PI. 1,fig. 5) (Bucur et al., 1993, Cociuba, 1995, Bucur \& Cociuba, 1998), association which continues from the previous member. The middle part of the Coposeni Member contains foraminifera and algae typical for the Lower Barremian, like: Paracoskinolina? jourdanensis FOURY \& MOULLADE (PI. 1, fig. 6), several species of Neotrocholia, Paracoskinolina and algae such as: Salpingoporella meiltae RADOIČIĆ, S. muehlbergii (LORENZ); at the upper part, species characteristic for Upper Barremian were identified: Palorbitolina lenticularis (BLUMENBACH) (PI. 1, fig. 7), Praereticulinella cuvillieri DELOFFRE, Rectodictyoconus sp.

2. Ecleja Formation (Patrulius et al., 1968, Patrulius et al., 1974, rap., Patrulius, in lanovici et al., 1976 = Ecleja beds; Cociuba, in Pop et al., 1998b = Ecleja Roşiorului Formation)

Definition: monotonous succession of partly siltic grey marls to marly silts, which in certain sectors present, in their lower part, interbeds of marly-limestone with yellowish alteration crusts, and blackish or violet limestone in beds of 0.5-2 m thickness (after Patrulius, in lanovici et al., 1976).

We consider that Gugu Breccia, separated by Patrulius et al., 1982, should be included in this formation as a "member", also taking into account that the carbonate interbeddings can be significantly thicker in the south-western part of Pădurea Craiului, thus the definition of the formation changes accordingly: a monotonous succession of partly siltic grey marls to marly silts, which in certain sectors contain in their basal part a carbonate massive breccia (with fragments of Cretaceous and Jurassic limestones and bauxite), marly-limestone with yellowish alteration crusts, and blackish or violet limestone with orbitolinids, in 0.5 to $2 \mathrm{~m}$ thick beds which sometimes reach up to 60-70 $\mathrm{m}$ in thickness.

Lower boundary: on the top of the last beds of limestone (or even bauxites) belonging to the previous formation. Lithological and erosional boundary.

Upper boundary: below the first beds of grey limestone in urgonian facies belonging to Valea Măgurii Formation. Lithologic and, in certain sectors, also erosional boundary.

Type-locality: the slope towards Mnerăie Valley of Ecleja Roşiorului (the northwestern end of Roşiorului Hill), north of Brejeşti.

Age: Early Aptian (Bedoulian), based on the foraminiferal assemblage (Cociuba, 1995; 1999) 
Remarks. It is worth to mention that the revision of the ammonite fauna (Avram et al., in press) significantly changed the previous interpretations; the most significant change refers to the assignment to genus Dufrenoyia of the forms that were previously attributed to genus Deshayesites. This change cancels the argumentation for the Basal Bedoulian age of the formation. It should be mentioned that no ammonite form was collected from the type-section and that we attributed all the locations from which biostratigraphically significant species originate to the basal part of the Vârciorog Formation.

The only outcrops which provided some poorly preserved ammonite specimens and which we consider to belong to the Ecleja Formation are located in Osiel Hill (Coposeni) and in the right slope of loanii Costanii Brook, near its junction with Văsiei Valley. The poor state of preservation or the species identified do not allow to specify the age of the formation.

2.1. Gugu Breccia- Member (Patrulius et al., $1982=$ Gugu Breccia)

Definition: breccia-type formation constituted of large boulders of Jurassic and Cretaceous limestones or even bauxites, with a chaotic but very compact display, centimeters to meters in size, cemented by sparitic calcite or red siltic material.

Lower boundary: on the top of the last beds of limestone (or even bauxite) belonging to the older formation (lithologic and erosional boundary).

Upper boundary: below the first beds of marly silts or stratified limestone with orbitolinids, in the basal part of Ecleja Formation.

Type-locality: at the source of Letii Valley (= upper part of Vida Valley) on the road Aştileu-Beiuş, between $\mathrm{km} 40$ and 41, where breccia overlay the Barremian limestone and are overlaid by a bank of black limestone followed by laminated grey marls belonging to Ecleja Formation.

Age: Early Aptian (basal Bedoulian).

2.2. Valea Bobdei Limestone Member nomen novum (Cociuba, $1995=$ middle pachyodonts limestone)

Definition: Succession of stratified grey or dark grey limestone in metric beds, with orbitolinids, lenticulinids, fragments of echinids and sometimes with terrigenous material (quartz fragment), which are interbedded between the laminated grey marls of Ecleja Formation. In the basal and the upper parts it includes also some beds of marls of metric thickness.

Lower boundary: below the first carbonate beds overlaying the marls and silty marls of the Ecleja Formation. marls.

Upper boundary: on the top of the last carbonate bank covered by grey silty

Type-section: Bobdei Valley, left side tributary of Măgura Valley, upstream from the limestone quarry from its junction with Văsiei Valley (Fig. 4).

Age: Early Aptian (Early Bedoulian), based on the foraminiferal assemblage.

Remarks: The limestone belonging to this member outcrops on Bobdei Valley, where both the lower and the upper boundaries are separated by deposits about $70 \mathrm{~m}$ thick. This thickness was previously incorrectly estimated to over $150 \mathrm{~m}$ (Cociuba, 1995, Fig. 2) taking into account the dips measured on the foliation of the 
marly rocks in the top and the base (see the comment on the relationship between stratification and foliation).

The foraminiferal and algal assemblage contains a great number of species which are common with the upper part of the Blid Formation (including Palorbitolina lenticularis (BLUMENBACH), PI. 2, fig. 5), but it can be individualized by the presence of several species: Sabaudia capitata ARNAUD-VANNEAU, Voloshinoides sp., ?Archaealveolina reicheli (DE CASTRO) (PI. 2, fig. 3), Paleodictyoconus cf. arabicus (HENSON), Salpingoporella sp. Also species of Orbitolinopsis (among which O. pygmaea ARNAUD VANNEAU, PI. 2, fig. 1), Netrocholina and Paracoskinolina are frequent, but species typical only for the Barremian are missing. The association is characteristic for Lower Aptian (lower Bedoulian).

3. Valea Măgurii Formation nomen novum (Patrulius, in lanovici et al., $1976=$ middle pachyodonts limestone)

Definition: a succession of grey or light grey limestones with metric beds, generally fine micritic but also pelmicrosparitic, with orbitolinids and rudists, which overlay the marls of the Ecleja Formation.

Lower boundary: below the first beds of fine limestone overlaying the grey stratified marls of Ecleja Formation (lithologic and sometimes erosional boundary) (Patrulius, 1974, rap., Patrulius, in lanovici et al., 1976).

Upper boundary: on the top of the last carbonate bank overlaid by marlydetrital deposits of Vârciorog Formation (lithologic and erosional boundary).

Type-section: the limestone quarry on Măgura Valley, near its junction with Văsiei Valley (north of Dobreşti village) (Fig.4). The upper part of the formation is very well opened in the upper part of the quarry while the lower part can be observed on a small torrent going towards the quarry in its eastern part, from Poniței peak (called "Hârtopul lui Onele"), where the marls of Ecleja Formation can be identified, downslope overlaid by limestone.

Age: Early Aptian (Late Bedoulian, pro parte.), based on foraminiferal assemblage.

Remarks: The lower part is very scarce in microfossils and is lighter in color. In several outcrops, subdecimetric siliceous concretions with a carbonate nucleus can be found; in the alteration crust, the dissolution of the limestone generate yellowish crusts (Arsurilor Valley, a right affluent of Peştişel Valley or in the left slope of Rogojele Valley).

The upper part of the formation is richer in fossils, at least in the typesection, being dominated by biopelsparites or biopelmicrosparites with foraminifers and rarely with algae, among which: Orbitolinopsis cuvillieri MOULLADE, Orbitolinopsis kiliani SILVESTRI, Orbitolinopsis buccifer ARNAUD-VANNEAU \& THIEULOY, Orbitolinopsis pygmaea ARNAUD-VANNEAU, Palorbitolina lenticularis (BLUMENBACH), Derventina filipescui NEAGU, Nautiloculina bronnimanni ARNAUD-VANNEAU \& PEYBERNES (PI. 2, fig. 2), ?Archaealveolina reicheli (DE CASTRO), Neotrocholina sp., Salpingoporella muehlbergii (LORENZ), Salpingoporella sp., Pseudoactinoporella fragilis CONRAD, Carpathoporella fontis (PATRULIUS).

This assemblage has a Bedoulian age and consists of several species which are similar with those of the Blid Formation and especially with Valea Bobdei Member. Pseudonummoloculina aurigerica CALVEZ (PI. 2, fig. 4) is the species identified by us only from Valea Măgurii Formation.

4. Vârciorog Formation nomen novum (Istocescu, 1969, lanovici et al., 
1976 = Glauconitic sandstone and upper limestone with pachyodonts complex; Kräutner, 1941 = flyschoid formation with interbedded black limestone with orbitolinids).

Definition: succession of grey or black marls, marly sandstones, glauconitic sandstones and dark grey to black limestone with orbitolinids and rudists. These deposits discordantly overlay a smooth paleorelief developed on the surface of the previous limestone (which sometimes host small amounts of ferruginous-bauxitic deposits), the whole succession reaching about 400-500 m thickness.

Lower boundary: on the top of the last beds of fine, grey limestone of the Valea Măgurii Formation (lithologic and erosional boundary).

Upper boundary: below the first red clayey-detrital beds of the overlaying formation (lithologic boundary).

Type-sections: the slope of pâclu Hill towards Copilului Valley for the lower part, and Gruiul Ciuții Valley, for the upper part (Fig. 6).

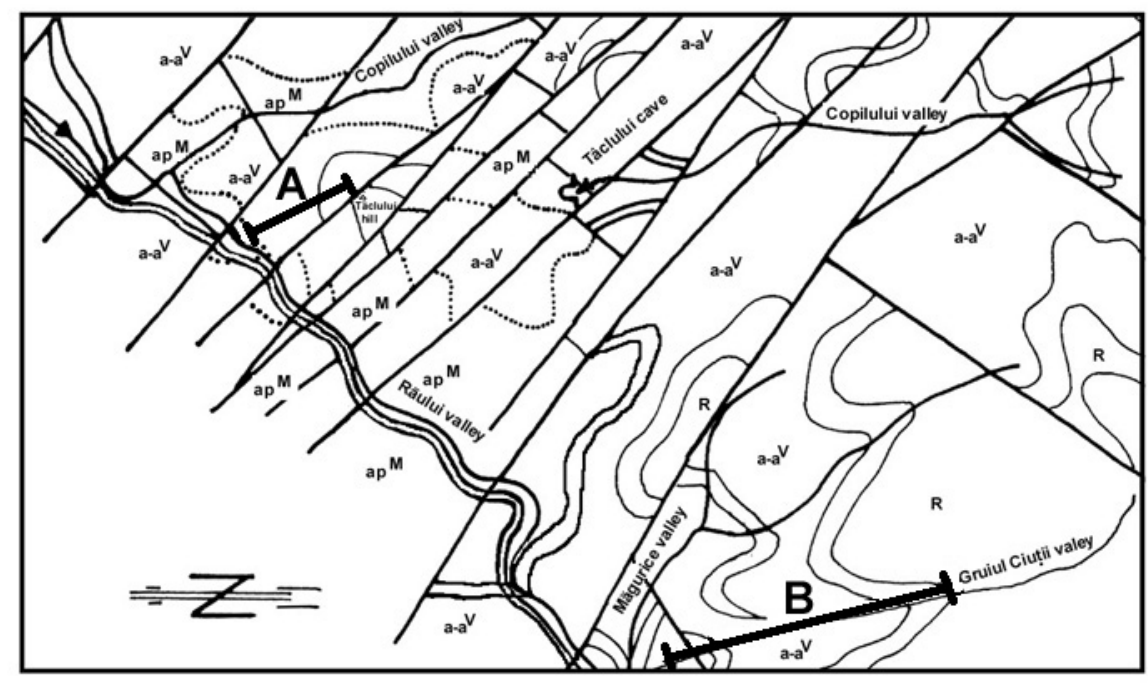

Fig. 6 - Location of the two complementary sections of the Vârciorog Formation (A - Pâclu Hill; B - Gruiul Ciuții Valley).

Age: Late Bedoulian pro parte- Gargasian - Albian.

Remarks: The lower part including the first thicker interlayer of limestone with rudists is opened in the left slope of Copilului Valley, near the junction with Răului Valley, on the north-eastern slope of Pâclu Hill. The upper part of this formation can be studied in the left slope of Măieşului Valley and on Gruiul Ciuții Valley, up to the first beds of red clays.

From the basal part of this formation, a rich fauna of ammonites was collected. It was attributed with no exception to Ecleja Formation, due to the lithology of the underlying rocks that is similar to the marls but also to the limestone at the boundary between Blid and Ecleja Formations. The whole collection, excepting the specimens mentioned by Fisch (1924) can be found at the 48 
Geological Institute of Romania. By courtesy of dr. Emil Avram, we had access this collection. The ammonite fauna was determinated and revised bt Avram (Avram et al., in press)

Remarks on the ammonite fauna. According to Avram et al. (in press), the lowest stratigraphical fossiliferous site are from the junction of Văsiei Valley with Măgurii Valley. Here, the presence of Dufrenoyia species is an index for $D$. furcata (d'ORBIGNY) zone (=Boverbanki Zone, after Casey, 1961). The most important feature concerning this association is the mixture of the last toxoceratoides, with Dufrenoyia- Colombiceras (C.)- C. (Egoianiceras) - Helicancylus genera, on a thickness not more than 2 to $3 \mathrm{~m}$. The same sequence was recognized, especially due to Dufrenoyia species, westwards from Varului Hill, Runcului Brook (on Văsiei Valley and not on Vida Valley!) and upstream towards Ponița Peak. The upper part of the outcrop in Varului Hill was the place of the first description in the Romanian references of the genus Mathoceras. This genus was known from Gargasian deposits (Martinoides Zone) in Venezuela (Renz, 1978), but also from Clansayesian (Nolani and Jacobi Zones), in Bulgaria (Avram et al., in press). In the same association species belonging to Pseudocrioceratites, known from the Clansayesian of the north Caucasus (Egojan, 1969) and the Albian of Sinai Peninsula (Douvillé, 1916), but also from the Barremian and Lower Bedoulian of Romania (Avram, unpublished), Simionescites (described from the Barremian - Bedoulian boundary, in Caucasus and Romania) and ?Tonohamites (in fact flattened fragments, similar but not identical' this genus was identified in formations not younger than Lower Aptian) were identified. The presence of species belonging to genera Parahoplites, and Acanthohoplites, indicate that the associations from the spring of Hotar Valley, south from Cornet, from Răului and Cubleşului Valleys have a Gargasian or a basal Lower Clansayesian age. Finally, the forms collected from the right slope of Hotar Valley and in "the eastern part of Varului Hill" (Istocescu et al., 1969), indicate a Clansayesian age due to the presence of Hypacathoplites. In this stage of our research it is not possible to establish the stratigraphic position of these levels in the synthetic column, due to the lack of cartographic data. The presence of species belonging to ?Tonohamites in the association in the quarry from Văsiei Valley suggests the presence of unrolled ammonites closely related to this genus in formations belonging to the whole Aptian.

Micropaleontological associations. In thin sections from samples of carbonate interlayers of Vârciorog Formation (collected in both outcrops and in Borehole no. 2 Hotar), we identified a rich foraminiferal and algal association with: Mesorbitolina texana (ROEMER) (PI. 2, fig. 6), Voloshinoides murgensis LUPERTO SINNI \& MASSE (PI. 2, fig. 7), Mesorbitolina subconcava (LEYMERIE) (PI. 2, fig. 8), Carpathoporella fontis (PATRULIUS), Sporolithon rudae (LEMOINE), Anisoporella? cretacea (DRAGASTAN), Pseudolithotamnium album (PFENDER), Meandorospira cf. washitensis LOEBLICH \& TAPPAN. 


\section{FORAMINIFERAL MICROFAUNA. BIOSTRATIGRAPHIC CONSIDERATIONS}

We identified almost 100 species of benthic foraminifers and calcareous algae in the Upper Jurassic and Lower Cretaceous deposits of the Pădurea Craiului Mountains. Their study was based on a detailed and documented theoretical knowledge that we gained in time, due to the value represented by the benthic organisms in shallow carbonate deposits.

The correlation of the shallow carbonate platform deposits was not an easy task for a long time, due to the lack of well-known biostratigraphical markers (ammonites and calpionellids). Such platforms are well represented in the Mesozoic of Tethys area, thus in time numerous informations accumulated, which finally allowed their correlation based on benthic organisms. These forms (foraminifers and calcareous algae) are abundant and almost exclusive within these deposits. Researchers from Romania studied and used them as biostratigraphical markers as soon as they gained the international acceptance for such purposes.

The microfossil (especially benthic foraminifers and dacycladal algae) study of thin sections is a specific tool in case of carbonate deposits that offers an acceptable biostratigraphic resolution, at a substage level. This resolution is still lower than that offered by the study of the planktonic organisms. The foraminifers and algae in the limestones of Pădurea Craiului were not studied in detail, in spite of the fact that since 1964 systematic geological exploration activity was undertaken for the bauxite accumulation located below the Lower Cretaceous limestones. The information we collected up to present (the species inventory and their vertical and horizontal distribution), compared with the inventory and biozonation of other geological units on the Romanian territory (Neagu et al., 1977; Costea et al., 1981; Costea et al., 1987; Dragastan, 1980; Bucur, 1997) as well as with the biozonation in the Tethys domain (Schroeder et al., 1968; Foury, 1968; Schroeder et al., 1978; Peybernés, 1976; Masse, 1976; Arnaud-Vanneau, 1980; Jaffrezo, 1980; Pélissié et al., 1984; Septfontaine et al., 1991; Mouty, 1997) allowed us to select some species with biostratigraphical value and some associations that can be used for discriminating and dating the various carbonate levels in the Upper Jurassic and Lower Cretaceous of Pădurea Craiului.

- Cornet Formation, outcropping in the southwestern part of Pădurea Craiului, was attributed by us to Oxfordian and not to the Oxfordian-Kimmeridgian?Tithonian, as mentioned previously. The paleontological argumentation is represented by the association with Alveosepta jaccardi (SCHRODT) (PI. 1, fig. 1), that was identified at the upper part of the formation. The association can be found also in the basal part of Albioara Formation. In the northern part of the massif, this formation reach probabely the Thitonian;

- Albioara Formation has a Kimmeridgian-Tithonian age (probably not more than Middle Tithonian), and not only a Tithonian one, or Tithonian-Berriasian, as considered previously. We attributed the age also based on the association with Alveosepta jaccardi (SCHRODT), which can be found in the basal part of this formation as well. In the same time the foraminifers and algae identified in the upper part of the formation (among which Parurgonina caelinensis PI. 1, fig. 3, Neokilianina rahonensis and Conicokurnubia aff. orbitolinideformis ) were used for dating Albioara Formation; 
- Dobreşti Member within Blid Formation was attributed to the ValanginianLower Hauterivian. If the bauxite in its basal part is considered, probably also the Berriasian should be considered. The association of foraminifers and algae that we identified consists, among others, of: Hapolphragmoides joukovskyi CHAROLLAIS et al., Montsalevia salevensis (CHAROLLAIS et al.), Meandrospira favrei (CHAROLLAIS et al.), Salpingoporella katzeri CONRAD \& RADOIČIĆ and Salpingoporella annulata CAROZZI.

- Coposeni Member within the same Blid Formation starts with the Valanginian-Hauterivian (the association mentioned previously is present also in the basal part of this formation) and continues up to Upper Barremian. In our opinion, in the south-western part of Pădurea Craiului the Barremian debuts at about $60-70 \mathrm{~m}$ from the level of the bauxite lenses and not right on the top of "the limestone with characeeans and gastropods".

- Ecleja Formation, considered previously to extend up to the Clansayensian, has in our opinion only a Bedoulian age. The Valea Bobdei Member, which was separated within Ecleja Formation, contains an association with several Bedoulian species, not found in younger deposits. The differences in the dating do not arise from paleontological arguments (the ammonite associations give unequivocal ages) but from the different formation identification according to the sampling points of the fauna. We consider that many of the forms cited from Ecleja Formation were, in fact, collected from Vârciorog Formation.

- Valea Măgurii Formation has an Upper Bedoulian age (pro parte), based on both the association of foraminifers and algae, and on the ammonite association hosted by the first bank of marls that unconformable cover the formation.

The foraminifer and algal associations includes: Paracoskinolina maynci CHEVALIER, Orbitolinopsis cuvillieri MOULLADE, Orbitolinopsis kiliani SILVESTRI, Orbitolinopsis buccifer ARNAUD-VANNEAU \& THIEULOY, Orbitolinopsis pygmaea ARNAUD-VANNEAU, Palorbitolina lenticularis (BLUMENBACH), Derventina filipescui NEAGU, Nautiloculina bronnimanni ARNAUD-VANNEAU \& PEYBERNES (PI. 2, fig. 2), ?Archaealveolina reicheli (DE CASTRO), Salpingoporella muehlbergii (LORENZ), Salpingoporella sp., Pseudoactinoporella fragilis CONRAD etc., species which are also common in the Valea Bobdei Member. Some species were identified only in Valea Măgurii Formation: Carpathoporella fontis (PATRULIUS) and Pseudonummoloculina aurigerica CALVEZ (PI. 2, fig. 4).

- Vârciorog Formation is attributed to the Uppermost Bedoulian - Albian interval, based on the ammonite associations at various levels but also based on the foraminifer and algae species which we identified in the limestone interlayers.

\section{PALEOGEOGRAPHIC AND TECTONIC EVOLUTION.}

\section{PALEOENVIRONMENTAL RECONSTRUCTIONS}

Over the condensed sediments of Dogger, showing numerous unconformities (suggesting a relative stability and a trend towards positive eustatic movements) in Pădurea Craiului area a carbonate platform sedimentation developed. It starts as early in Upper Callovian with external slope, hemipelagic-type facies, on a slope with a reduced inclination (limestone belonging to Vad Formation). These facies are typical for the central-northern area, where they characterize the sedimentation until the Oxfordian (probably also during the Kimmeridgian). In the south and southwestern parts of Pădurea Craiului area these depositional environments 
either are missing or they developed for a relative short while (the corresponding sediments are very thin) and instead reefal or perireefal facies developed (the limestone of the Cornet Formation).

At the end of Oxfordian the reefal barrier migrated towards north (where the limestones of the Vad Formation are replaced by those of the Cornet and Aştileu Formations); in the southern part, an internal lagoonal environment instaled (isolated from the open sea by the northern reefal bars), which allowed the formation of the oncolithic or fenestral-micritic limestone of the Albioara Formation. The thick beds of shallow limestone deposited meanwhile suggest a constant subsidence rate compensated by the sedimentary rate. The lack of terrigenous material is relevant and signifies the lack of a direct connection with the continent or a long distance from it.

According to all the results of this study, at the end of Middle Tithonian, the end of the subsident trend and the passage to slightly positive eustatic movements lead to the interruption of the carbonate sedimentation. The surface of the Jurassic limestones was submitted to emersion on the whole area of the Pădurea Craiului Mountains.

From the end of Middle Tithonian until the Early Valanginian the surface of the limestones was modeled by karst-type processes on a carbonate plateau of reduced altitude, similar with the present-day ones from Central America (Pop \& Mârza, 1977). These conditions also favored the accumulation of diaspore bauxite in the paleodolines.

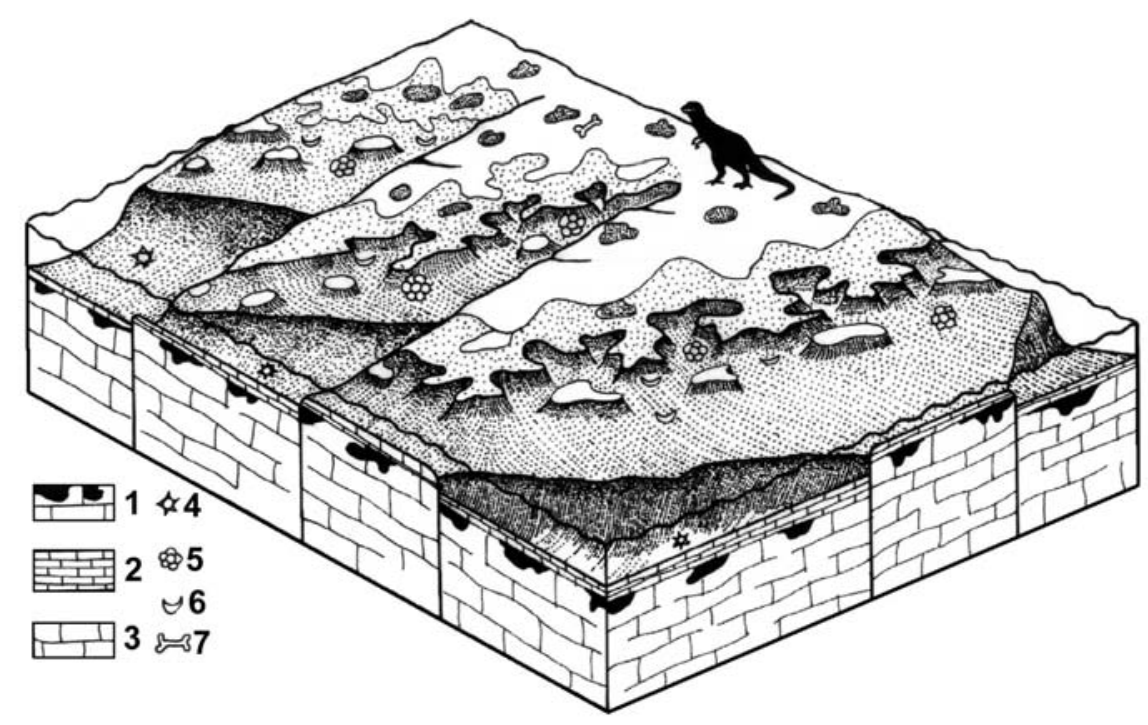

Fig. 7. Reconstruction of the sedimentary environment within the Dobreşti Member (according to Bucur \& Cociuba,1998). 1. Bauxites in the paleorelief of Upper Jurassic limestones; 2. Limestones with characeeans and gastropods; 3 . Upper Jurassic limestones; 4. Dasyclads; 5. Characeeans; 6. Ostracodes; 7. Dinosaure bones.

The oldest sedimentary deposits which cover the bauxites are generally 
developed in a freshwater environment. Our study identified in the extreme northern area a first marine intercalation as well as several interlayers with a paleontological content proving the marine influence at several levels within the characeeans limestone on the top of the bauxite. At least two hardground surfaces can be noticed in several places in the southwest and north of Pădurea Craiului, which plead for the uplift of the limestone surfaces above the water level. In this way more or less pronounced paleorelief surfaces formed, where polychromatic marly clays (with characeeans) or boehmitic bauxites with rests of dinosaurs formed (Fig. 7).

The limestones deposited during the Hauterivian and Barremian prove the existence of normal marine environments dominated by the internal ones (micrites with fenestral laminations, micrites with dacycladaceans and fragments of rudists), which were protected by the offshore currents through not very prominent oolite bars. Rarely external platform facies are also present (coarse biosparites with orbitolinids, algae and rarely echinoderms).

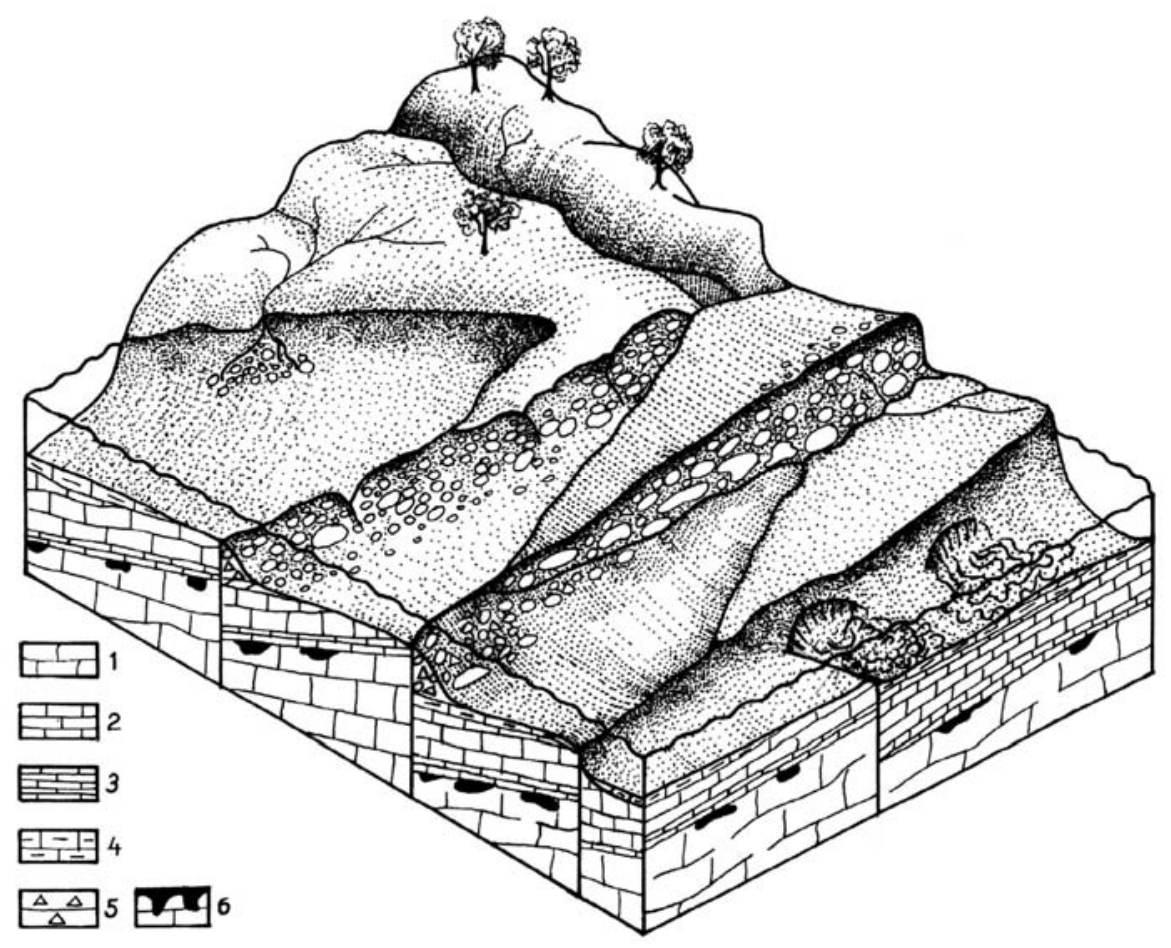

Fig. 8. Reconstruction of the sedimentary environment within the Breccious Gugu Member (according to Bucur \& Cociuba, 1998). 1. Upper Jurassic limestones; 2. Limesones of Blid Formation 3. Limestones with characeeans and gastropods of Dobreşti Member; 4. Marly-limestones of Ecleja Formation; 5; Gugu Brecia Member; 6. Bauxites in the paleorelief of Upper Jurassic limestones; 
At the end of Barremian significant tectonic movements lead to the separation of the platform into blocks with very different vertical movement trends, which produced the conditions of accumulation for slope breccias in continental regime (Gugu Breccia Member). It is possible that in the same time most of the major structures of Pădurea Craiului to have formed: Culmea Roşiorului anticline, Crucii Hill anticline etc. and, generally speaking, horsts and grabens (Patrulius et al., 1982). These tectonic movements caused fundamental changes in the sedimentation regime by changes in the altitude differences, which lead to a massive terrigenous supply on external slopes with relative high inclinations and a pronounced subsidence (Fig. 8). Under these circumstances, the carbonate sedimentation is replaced by a brecciatype or a silty-marly one, with numerous intraformational gravitational shifts, as present in Ecleja Formation. The decrease, even temporary, of the subsidence rate leaded to the formation of environments that favored the accumulation of the external slope limestone with echinids and lenticulinids (the limestone of the Valea Bobdei Member). Such an event, which took part towards the end of Bedoulian, lead to the installation of depositional environments very similar to the Barremian ones (internal protected environments), in which the limestone of the Valea Măgurii Formation deposited. At the end of Bedoulian a reduced uplift of these limestones took place (the ferruginousbauxitic term in the basal part of Vârciorog Formation), as a result of the reversal of the sense of the eustatic movements.

The reinstallation of the detrital sedimentation with an increased terrigenous supply proves a new reactivation of the landscape differences in the emerged areas. The carbonate interlayers become thinner and richer in terrigenous material while the whole succession presents flysch-type features.

During, or after the Albian (until the Middle Turonian), the deposition of red detrital clay-rich sediments was a result of the increase of the continental influence due to the continuous landscape regeneration, in connection with the emplacement of the overthrust nappes. Thus, according to the sedimentary processes, the intra-turonian moment represents the end of an overthrust process in the northern area of the Apuseni Mountins. (in the southern area the overthrust movement that lead to the formation of overthrust nappes continued). The mid-cretaceous movements practically mark the close-up of the European sector of Tethys, as an ocean floor-type basin (Săndulescu, 1984).

\section{RELATIONSHIP BETWEEN THE BEDDING AND FOLIATION WITHIN THE ECLEJA AND VÂRCIOROG FORMATIONS}

Most of the authors who previously mapped Pădurea Craiului Mountains noticed the presence of structural differences between the areas dominated by limestones, showing generally tabular morphologies with inclinations up to $25^{\circ}$, and the areas dominated by marly facies, where the inclinations rise suddenly to more than $45^{\circ}$. These differences were explained by the different tectonic competence evidenced during the mid-cretaceous movements. One of the consequences of this theory was the attribution of very significant thickness (up to more than $1000 \mathrm{~m}$ ) to the marly formations. 
For clarifying this structural problem we performed very many measurements in the outcrops, which we correlated with the positions of the formation boundarys as defined by the geological mapping. In none of the cases, the two types of data were concordant. Recently exposed outcrops that were not submitted to weathering, which show both the bedding and foliation of the rocks offered the explanation. In the same time, we noticed that the discoidal shapes of the ammonites crosscut the "bedding". In conclusion, according to our observations, the measurable element in the outcrops in both Ecleja and Vârciorog Formations is represented mainly by a stress foliation that cross the original stratification, most probably as a result of the tectonic effects caused by the midcretaceous overthrusts.

The original bedding can be hardly observed in fresh outcrops, especially in the case where significant lithological variation is present (thicker beds of limestone, coarse sandstones or conglomerates), at the transitional boundary from thick carbonate formations to those dominated by marls. As an example, we can mention the transition from Blid Formation to Ecleja Formation (on Osoi Hill and Hârtopul Zăpezilor, near Coposeni) or that from Valea Măgurii Formation to Vârciorog Formation (the quarry in Văsiei Valley, along Copilului Valley, on Surducelului Valley, $300 \mathrm{~m}$ from its junction with Peştişel Valley etc).

Such a demonstrative situation can be seen at the upper part of the quarry located at the junction of Măgurii Valley with Văsiei Valley, which is one of the classical fossiliferous sampling point for ammonites. In this place, at the transition level (showing a slight unconformity) between the limestone of the Valea Măgurii Formation to the marly-sandstones, the surface of the last bank of limestone shows an orientation of $20^{\circ}$, with $0^{\circ}$ dip, in a similar way as in the case of the first beds of marls along $3 \mathrm{~m}$ thickness. However, along the altered surfaces the last formation shows a foliation trend with $45^{\circ} / 0^{\circ}$ dip, as well as the deformation of the ammonite macrofauna (well represented in the outcrop and aligned according to the stratification) perpendicular to the foliation. At an upper level in the outcrop the grayish-reddish marls only preserve the foliation along $45^{\circ} / 0^{\circ}$ dip.

The same stratigraphic level, in similar conditions, can be noticed in several places along the left slope of Copilului Valley, in its lower course, not far from its junction with Răului Valley. Many of the ammonite samples that preserve the host-rock evidence the difference between the orientation of the fossil (along the stratification) and the schistosity of the rock.

The most important consequence of such a difference between the rock stratification and schistosity is the particular structural interpretation in case of the areas covered by marly rocks, which were attributed thickness significantly reduced as compared to the real ones. The structural differences between the areas dominated by carbonate formations (especially of a Malm-Barremian age) and those dominated by marly-detrital facies (Ecleja and Vârciorog Formations) are considered as artifacts in this new interpretation; the only differences are represented by the presence of some intraformational folds caused by slope flows in the case of the last ones.

\section{CONCLUSIONS}

The present paper represents an attempt to review of the Upper Jurassic Lower Cretaceous deposits within the Bihor Unit in the Pădurea Craiului Mountains, according to the Inernational Stratigraphical Guide. Based on mapping, 


\section{IOAN COCIUBA}

and on a detailed sampling especially of the carbonate formations, a new stratigraphic column and geological structure was drawn. The age of each formation was documented based on the benthic organisms, but also on the ammonite species where available.

The following units represent the Upper Jurassic: Vad, Cornet, Aştileu, and Albioara Formations (the last one divided into Secătura and Valea Cuților members). The Lower Cretaceous includes Blid Formation (divided into Dobreşti and Coposeni Members), Ecleja Formation (partly divided into Gugu and Valea Bobdei members), Valea Măgurii and Vârciorog formations respectively.

The data available allowed us to prove the age of the formations described, to reconstruct the paleoenvironments and to give a structural interpretation, significantly differing from the previous ones.

\section{Acknowledgemets}

I thank Dana Pop for the English translation, Emanoil Săsăran for computer redrafting of the Fig.1, and I.I. Bucur and S. Filipescu for reviewing the manuscript.

\section{REFERENCES}

1. Arnaud-Vanneau A. (1980): Micropaléontologie, paléoécologie et sedimentologie d'une plateforme carbonatée de la marge passive de la Téthys: l'Urgonien du Vercors septentrional et de la Chartreuse (Alpes occidentales). Geologie Alpine, Mém. 11, 874p., Grenoble.

2. Avram E., Bordea S., Cociuba I., Huza R., Preda I. (in press): Ammonite assamblage of Ecleja Formation (Northern Apuseni Mts., Romania). Jurnal of Paleont., Bucureşti.

3. Azéma J., Chabrier G., Fourcade E., Jafrezo M. (1977): Nouvelles donnés micropaléontologiques stratigraphiques et paléogéographiques sur le Portlandien et le Neocomien de Sardaigne. Rev. de Micropal., Vol. 20, n. 3, p. 125-139, Paris.

4. Bardossy G. (1977): Karszt bauxitok (Bauxittelepek karbonátos kőzeteken). Acad. Kiadó. 413 p., Budapesta.

5. Bordea S., Istocescu D. (1970): Contribuții la studiul stratigrafic al Cretacicului (NeocomianTuronian) din partea vestică a Munților Pădurea Craiului. D. S. Inst. Geol., vol. LV (1976-1968), 4, p. 49-58, Bucureşti.

6. Bordea S. Bordea J. (1987): Note préliminaire sur la présence des Orbitolinidés primitifs du Calcaire d'Albioara (au sud de Pădurea Craiului, Monts Apuseni). D. S. Inst Geol. Geofiz., vol 7273/4, p. 45-53, Bucureşti.

7. Bucur I. I., Cociuba I., Cociuba M. (1993): Microfacies and microfossils in the Upper Jurassic Lower Cretaceous limestone in the southern part of the Pădurea Craiului Mountains. Rom. J. Stratigraphy, vol. 75, p. 33-40, Bucureşti.

8. Bucur I. I., Cociuba I. (1996): Microbiostratigraphic markers in the Lower Cretaceous deposits from Pădurea Craiului Mountains (Northern Apuseni Mountains). An. IGR, 69, suppl. 1, p. 40-43, București.

9. Bucur I. I. (1997): Formațiunile mezozoice din zona Reşița-Moldova Nouă, Edit. Presa Univ. Clujană, 214 p., 32 pl., Cluj-Napoca.

10. Bucur I. I., Cociuba I. (1998): La plate-forme carbonatée du Crétacé inférieur des Monts Pădurea Craiului (Monts Apuseni, Roumanie). Biostratigraphie et configuration. Studia Univesitatis Babeş-Bolyai, Geologia, XLIII/2, p. 89-100, Cluj-Napoca.

11. Cociuba I. (1995): Forminfères bénthiques dans les dépôts du Jurassique supérieur et du Crétacé inférieur des Monts Pădurea Craiului. Stud. Cerc., Vol. 1, p. 119-133, Bistrita.

12. Cociuba I. (1999): Studiul stratigafic al depozitelor mezozoice din sud-vestul Pădurii Craiului. 56 
Teză de doctorat- Universitatea Babeş-Bolyai, 253 p., 56 pls., Cluj Napoca.

13. Costea I., Vinogradov C., Comşa D., Bönig H. (1981): Studiul microfacial al depozitelor cretacice din Platforma Moldovenească şi Depresiunea Bârladului. St. cerc. geol., geofiz., Geologie, vol. 26/2, p. 275-295, Bucureşti.

14. Costea I., Comşa D., Vinogradov C. (1987): Microfaciesurile Cretacicului inferior din platforma Moesică. Stud. Cerc. Geol., Geophis., Geogr., Geologie, t. 23, 2, p. 299-311, Bucureşti.

15. Dragastan O (1980): Alge calcaroase din Mesozoicul si Terțiarul României, 169 p., Edit. Acad. R.S.R., București.

16. Dragastan O., Purecel R., Brustur T. (1986): The Upper Jurssic and Lover Cretaceous Formations from the Bihor Mountains - central - southern sector (Northern Apuseni). An. Univ., Buc. vol. 35, p. 57-70, Bucureşti.

17. Dragastan O., Coman M., Ştiucă E. (1988): Bauxite-bearing formations and facies in the Pădurea Craiului and Bihor Mountains (Nortern Apuseni). Rev. Roum. Geol. Geophys., geol, vol. 32, p. 67- 81, Bucureşti.

18. Dragastan O., Diaconu M., Popa E., Damian R. (1982): Biostratigraphy of the Triassic formations in the east of Pădurea Craiului Mountains. D. S. Inst. Geol. Geofiz., vol. LXVII/4 (19791980), p. 29-61, Bucureşti.

19. Fisch W. (1924): Beiträge zur Geologie des Bihargebiges. Jahrb. der Philosoph. Fak. der Univ Bern, vol. VI, p. 114-135, Bern.

20. Foury G. (1963): Le Crétacé inférieur des Alpilles, contribution à l'étude stratigaphique et micropaléontologique. Geobios, 1, p. 119-164. Lyon.

21. Hedberg H. D. (1976): International Stratigraphic Guid. Second ed. (A. Salvador ed., 1994), 214 p., The Geol. Soc. of America, Boulder.

22. lanovici V., Borcoş M., Bleahu M., Patrulius D., Lupu M., Dimitrescu R., Savu H. (1976): Geologia Muntilor Apuseni. Edit. Acad. R. S. România, 631 p., Bucureşti.

23. Istocescu D. (1969): Stratigrafia şi fauna depozitelor Creacice din zona Vârciorog - Copăcel (nord-vestul Pădurii Craiului, Munții Apuseni)., D. S. Inst. Geol. vol. LIV (1966-1967), 4, p. 161164, Bucureşti.

24. Jaffrezo M. (1980): Les formations carbonateés des Corbières (France) du Dogger à l'Aptien: Micropaléontologie, stratigraphie, biozonation, paléoécologie. Extension des rezultats à la Mésogée. Thése Doct. Etat Sci. Univ. P. M. Curie, 823 p., Paris.

25. Jurcsak T., Popa E (1978): Resturi de dinozaurieni în bauxitele de la Cornet. Nymfaea. Folia naturae Biharie, vol. VI, p. 61-64, Oradea.

26. Kräutner T. (1941): Etudes géologiques dans la Pădurea Craiului. C.R. Inst Geol. vol. XXV (1936-1937), p. 145-156, Bucureşti.

27. Masse J.-P. (1976): Les calcaires urgoniens de Provence (Valanginian-Aptien). Stratigraphie, paléontologie, les paléoenvironnements et leur évolution. Thèse Doct. D'Etat, Univ. Aix-Marseille, vol. I, II, 445p., Marseille.

28. Mouty M. (1997): Le Jurassique de la Chaîne Côtière (Jibal Ab-Sahiyeh) de la Syrie: essai de biozonation par les grands foraminifères. C. R. Acad. Sci. Paris, ser. II, t. 325/3, fasc. A, p. 207231, Paris.

29. Neagu Th., Pană I., Dragastan O. (1977): Biostratigraphie de la serie des calcaires eocretacés de l'aire Cernavodă -Alimanu - Ostrov., Rev. Roum. Geol., Geophys., Geogr., Geologie, t. 21, p. 137-144, Bucureşti.

30. Patrulius D. (1956): Contribuții la studiul geologic al Pădurii Craiului (comunicare preliminară). D. S. Com. Geol. vol. XL (1952-1953), p. 116-127, Bucureşti.

31. Patrulius D., Lupu M., Borcoş M. (1968): Harta geologică a R.S.R., scara 1:200.000. Notă explicativă pentru foaia 9, Şimleul Silvaniei, Edit. Inst. Geol., 44 p., Bucureşti.

32. Patrulius D., Mantea G., Bordea S., Bordea J., Popa E., Ştefănescu M.(1974, raport): Studiul de sinteză al formațiunilor tithonice şi barremiene din Autohtonul de Bihor, între Crişul Repede şi Somesul Cald, în vederea descoperiri de noi perimetre purtătoare de zăcăminte de bauxită., Raport arhiva I.G.R., Bucureşti.

33. Patrulius D., Popa E.., Tomescu C., Popescu E., lordan M., Pop G., Panin S., Bordea S. (1982, 


\section{IOAN COCIUBA}

raport): Cercetări biostratigrafice pentru corelarea formațiunilor mezozoice. Jurasicul si Neocomianul din Munții Apuseni de Nord. Raport, Arhiva I. G. R. Bucureşti.

34. Patrulius D., Bordea S., Avram E. (1982): La brèche de Gugu. Un exemple de controle téctonique de la sédimentation sur une plate-forme carbonatée barremo-bedouliènne (Pădurea Craiului, Monts Apuseni). D. S. Inst. Geol., vol. LXVI, n. 4, p. 109-117, Bucureşti.

35. Patrulius D. (1971): Unitatea de Vălani: un nou nou element structural al sistemului pânzelor de Codru (Munții Apuseni). D.S. Inst. Geol., vol. LVI (1969-1970), 5, p. 155-171, Bucureşti.

36. Pélissié T., Peybrernés B. \& Rey J. (1984): Les grands foraminières benthiques du Jurassique moyen/superieur du sud-ouest de la France (Aquitaine, Causses, Pyrénées). Intérêt biostratigraphique, paléoécologique et paléobiogéographique. Benthos'83, 2nd Int. Symp. Benthic Foram., p. 479-489, Pau.

37. Peybernès B. (1976): Le jurassique et le Cretacé inférieur des Pyrenées franco-espagnoles entre la Garonne et la Méditeranée. Thèse Doct. Sc. Nat., Univ. Paul Sabatier, 459 p., Impr. C.R.D.P., Toulouse.

38. Pop G., Melinte M., Grigore D., Cociuba I. (1998b, raport): Studii biostratigrafice asupra depozitelor mezozoice şi neozoice din România (tema A8/1998). Stratigrafia depozitelor neojurasice şi eocretacice din România. Raport de etapă, arhiva I.G.R. Bucureşti.

39. Pop G., Mârza I. (1977): Le paléocarst éocretacé des Monts Pădurea Craiului et sa signification dans la genèse des bauxites. Sci. Geoll. Bull., vol. 30, 1, p. 51-58, Strasbourg.

40. Popa E. (1981): La biostratigraphie des formations mésozoiques de la partie orientale de Pădurea Craiului (Monts Apuseni). An. Inst. Geol.Geofiz., vol. LVIII, p. 203-282, 9 figs., 22 pls., hartă sc. !:25.000, Bucureşti.

41. Preda I. (1963): Geologia regiunii Lunca Sprie, Corbeşti, Valea Râului, Surducel. Soc. Şt. Nat. Geogr., Comunicări de Geologie, vol. II, p. 198-205, Bucureşti.

42. Săndulescu M., Russo-Săndulescu D.(1981) - Harta geologică a României, scara 1: 50000 foaia 19a (Poiana Botizii). I.G.R., Bucureşti.

43. Săndulescu M. (1984): Geotectonica Romaniei. Ed. Tehnică, 336 p., Bucureşti.

44. Schroeder R., Charollais A., Conrad M.-A. (1968): Essai de biozonation au moyen des orbitolinidés dans les calcaires urgoniens de la Haut-Savoi et de l'Ain, France. C. R. Acad. Sci. Paris, vol. 267, p. 390-393, Paris.

45. Schroeder R., Cherchi A., Guellal S., Vila J., M. (1978): Biozonation par les grands Foraminifères du Jurassique supérieur et du Cretacé inféruieur et moyen des séries néritiques en Algerie NE. Considérations paléogégraphiques. Ann. Mines Geol., VI Col. Afric. de Micropal., 28 , 2, p. 243-253,Tunis.

46. Septfontaine M. (1988): Vers une classification evolutive des Lituolidés (Foraminifères) jurassiques en milieu de plate-forme carbontée. Rev. Paléobiol. vol special, n. 2, p. 229-256, Geneva.

47. Septfontaine M., Arnaud-Vanneau A., Bassoullet J.-P., Gusic Y., Ramalho M., Velic I. (1991): Les foraminifères imperforés des plates-formes carbonatées jurassiques: état des connaissances et perspectives d'avenir. Bull. Soc. Vaud. Sc. Nat. vol. 80/3 (Bull. Géol. Musée Lausanne, vol. 312), p.255-277, Lausanne.

48. Szontagh T. (1904): Rev-Biharkalota és á Vidavalgni telep (Kiralyerdö) geolgiai viszganyai. M. K. Föld. Intézet évi jelent. 1903-röl, p. 68-64, Budapest.

49. Tasli K. (1993): Micropaléontologie, stratigraphie et environement de depôt des series jourassiques á facies de plate-forme de la region de Kale-Gümüshane (Pontides orientales, Turquie). Rev. Micropal., vol. 36, n. 1, p. 41-65, Paris. 
UPPER JURASSIC - LOWER CRETACEOUS DEPOSITS OF PĂDUREA CRAIULUI

\section{PLATES EXPLANATION}

\section{PLATE 1}

Fig. 1. Alveosepta jaccardi (SCHRODT), 1894, thin section 1020-464, Dealul Pleş Valea Cuților, Cornet Formation;

Fig. 2. Haplophragmoides joukovskyi CHAROLLAIS et al., 1966; thin section 697-Pop, F. 3 Peştere, m 293, Blid Formation, Coposeni Member;

Fig. 3. Parurgonina caelinensis CUVILLIER, FOURY \& PIGNATI MORANO, 1968; thin section 995-438, Dealul Pleş - Valea Cuților, Albioara Formation;

Fig. 4. Salpingoporella katzeri CONRAD \& RADOIČIĆ, 1978; thin section 1527-2713, Valea Vida-Coposeni, Blid Formation, Coposeni Member;

Fig. 5. Montsalevia salevensis (CHAROLLAIS et al.), 1966; thin section 722-Pop, F. 3 Peştere, $m$ 345, Blid Formation, Dobreşti Member;

Fig. 6. Paracoskinolina? jourdanensis FOURY \& MOULLADE, 1966; thin section 1375-1234, Valea Ticaşului, Blid Formation, Coposeni Member;

Fig. 7. Palorbitolina lenticularis (BLUMENBACH), 1805; thin section 1203-903, Hârtoapele Zăpezii, Blid Formation, Coposeni Member;

Scale bar dimension: Fig. $1=0,8$ mm, Fig. 2, 4-7=0,2 mm, Fig. $3=0,4$ mm

\section{PLATE 2}

Fig. 1. Orbitolinopsis pygmaea ARNAUD-VANNEAU, 1980; thin section 1313-1114, Valea Bobdei, Valea Bobdei Member;

Fig. 2. Nautiloculina bronnimanni ARNAUD-VANNEAU \& PEYBERNĖS, 1978; thin section 261-252, F. 5 Valea Văsiei, m 43, Valea Măgurii Formation;

Fig. 3. ?Archaealveolina reicheli (DE CASTRO), 1966; thin section 1302-1103, Valea Bobdei, Valea Bobdei Member;

Fig. 4. Pseudonummoloculina aurigerica CALVEZ, 1988; thin section 324-318, F. 5 Valea Văsiei, $m$ 310, Valea Măgurii Formation;

Fig. 5. Palorbitolina lenticularis (BLUMENBACH), 1805; thin section 1705-2822, Pârâul loanii Costanii, Valea Bobdei Member;

Fig. 6. Mesorbitolina texana (ROEMER), 1849; thin section 1669-1997, Dâclu Hill, Vârciorog Formation;

Fig. 7. Voloshinoides murgensis LUPERTO SINNI \& MASSE, 1993; thin section 75945, F. 2 Hotar, m 294, Vârciorog Formation;

Fig. 8. Mesorbitolina subconcava (LEYMERIE), 1878; thin section 765-51, F. 2 Hotar, m 341, Vârciorog Formation;

Scale bar dimension: Fig. 1, 2, 4-8 = 0,2 mm, Fig. $3=0,4 \mathrm{~mm}$. 
IOAN COCIUBA

\section{PLATE 1}
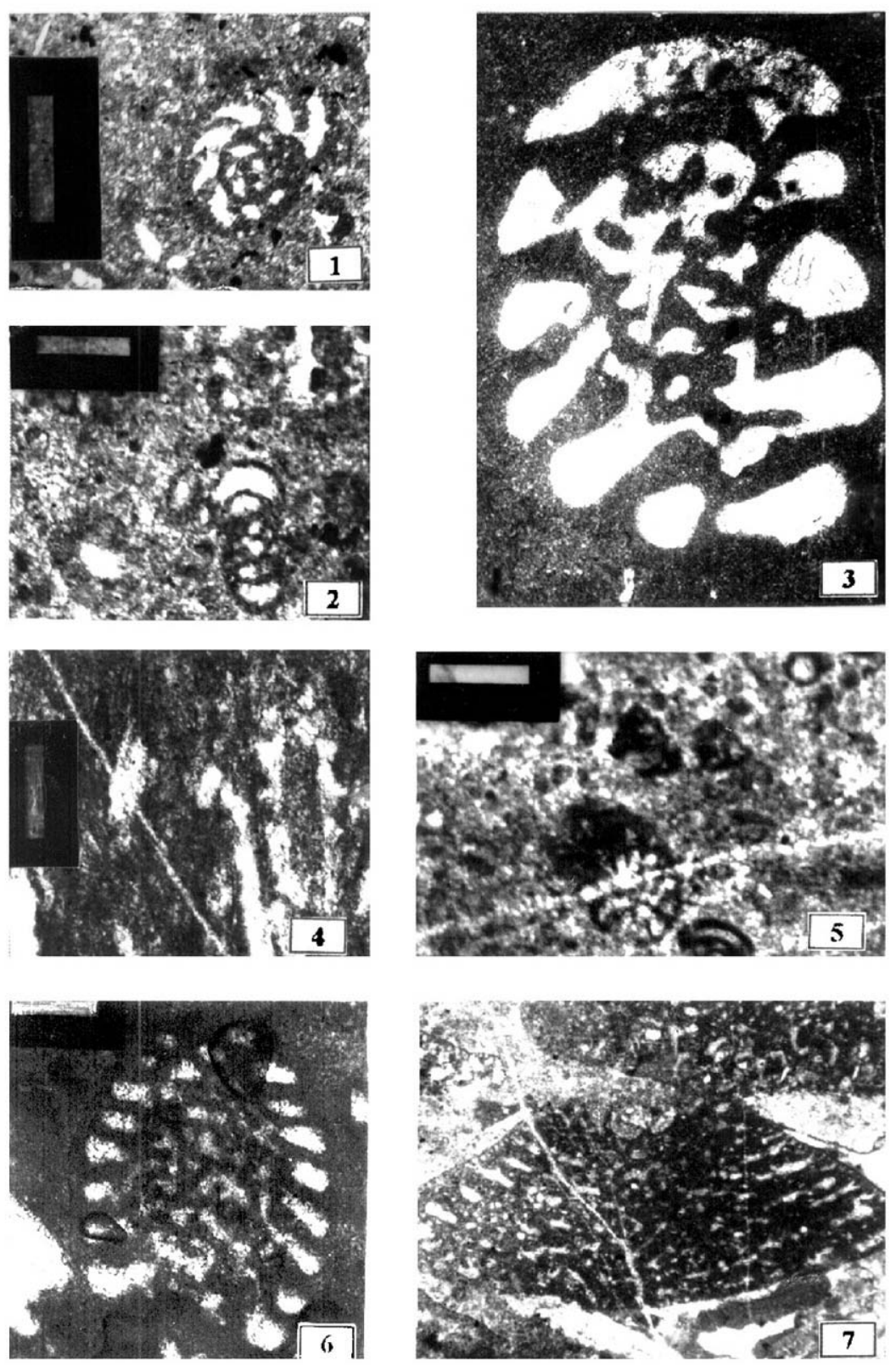


\section{PLATE 2}
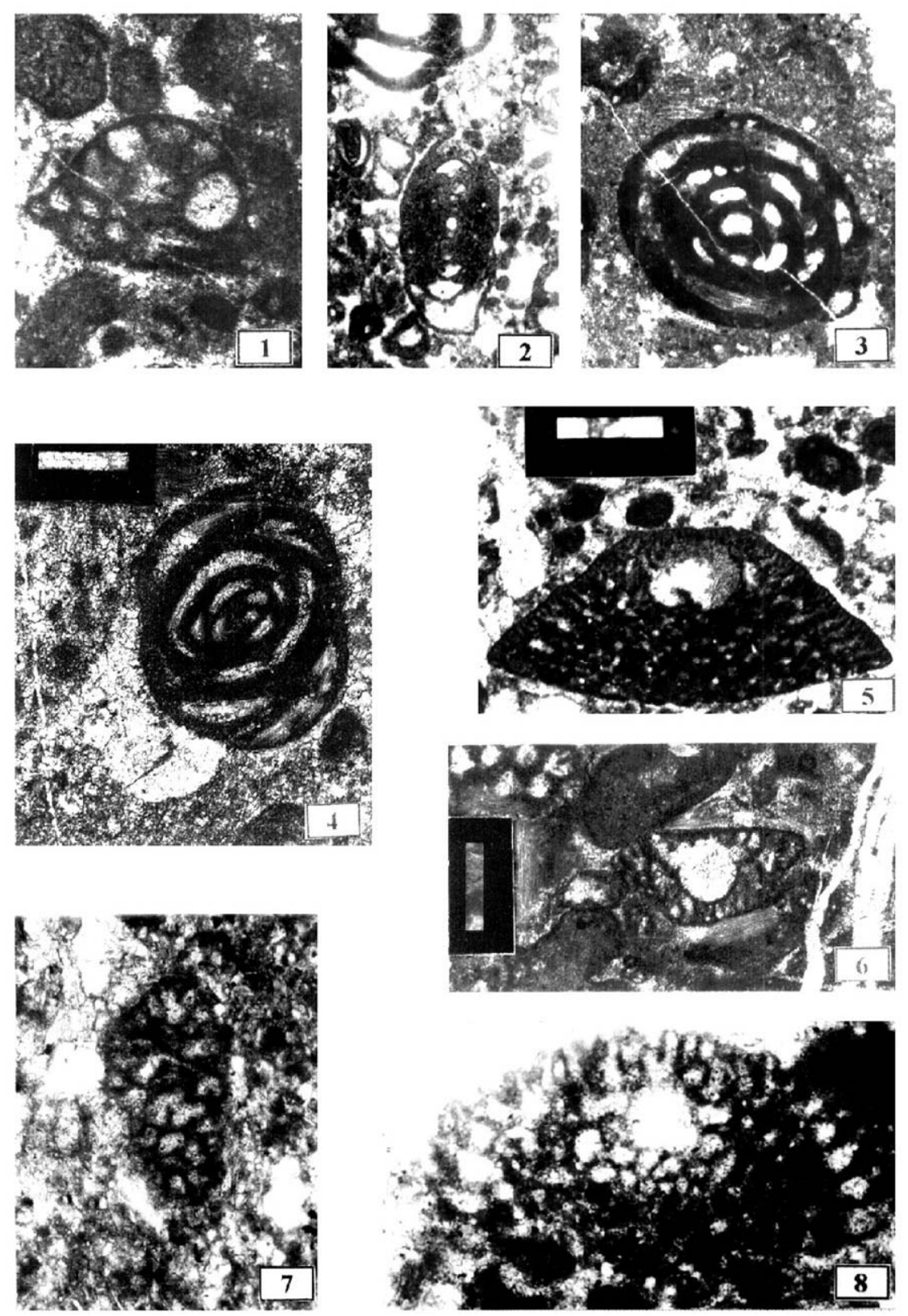